\title{
A patient of severe acute renal failure secondary to obstructive uropathy with an optimal outcome
}

\author{
Ranjit Chaudhary, Kulwant Singh, Rakesh Biswas, Rahul Chaudhary, Nidhi Jain
}

People's College of Medical Sciences, Bhopal, India

Correspondence to Ranjit Chaudhary, drnidhiranjit@gmail.com

\section{DESCRIPTION}

A 22-year-old male presented with complaints of bilateral flank pain along with nausea and vomiting since 2 weeks. There was anuria since 2 days. Routine blood investigations revealed deranged renal function tests, blood urea was $132.7 \mathrm{mg} \%$ and serum creatinine was.14.7 $\mathrm{mg} \%$. Serum electrolytes, electrocardiogram (ECG) and arterial blood gas $(A B G)$ levels were within normal range. Ultrasonogram showed bilateral renal and ureteric stones with moderate hydronephrosis. Plain skiagram kidney, ureter, bladder (KUB) revealed multiple right renal and ureteric stones; there was a solitary left renal stone and two stones in left lower ureter (figure 1).

Ultrasonography-guided bilateral per cutaneous nephrostomies were inserted under local anaesthesia (figure 2). Subsequent urine output was $1500-2000 \mathrm{ml}$ on both sides. Appropriate fluid replacements were made and miraculously serum creatinine came down to $1.7 \mathrm{mg} \%$ after just 1 week of diversion.

After stabilisation, the patient was subjected to endoscopic removal of stones. We used a semirigid ureteroscope and a rigid nephroscope. In one sitting, right ureterorenoscopy (URS) was done followed by left URS and left percutaneous nephrolithotomy (PCNL) achieving complete clearance of both ureters and left kidney (figure 3). After 3 days, we performed right PCNL and removed left double J (DJ) stent. Prior to this a right nephrostomogram was done

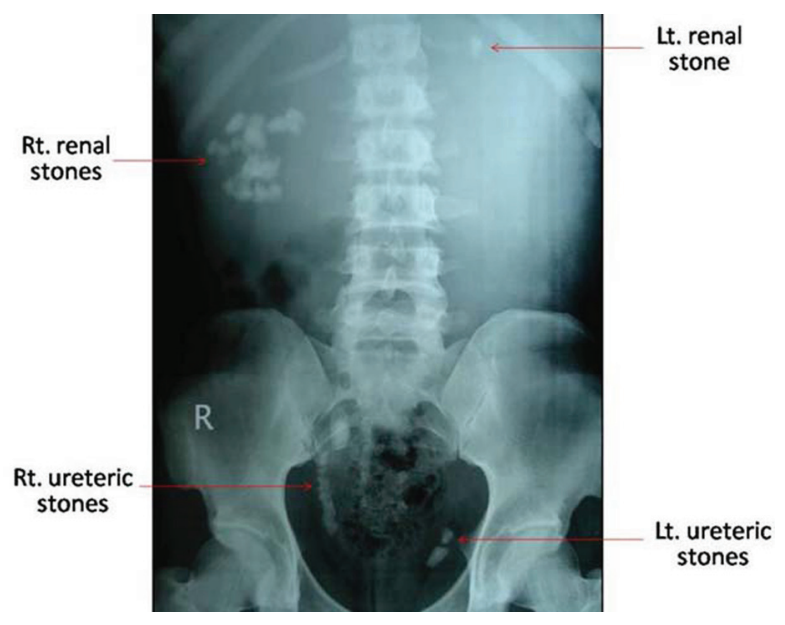

Figure 1 Plain skiagram KUB region. Multiple right renal and ureteric stones, solitary left renal stone and two stones in left lower ureter. (figure 4). All stones in the right kidney were removed employing three punctures and right DJ stent was kept (figure 5). No blood transfusions were needed. Patient was discharged after 3 days of second procedure and right DJ stent was removed after 3 weeks. The serum creatinine at the time of discharge was $1.31 \mathrm{mg} \%$ and all punctures had completely healed (figure 6).

\section{DISCUSSION}

On presentation, the renal functions showed gross derangements. However, since serum electrolytes, ECG and $A B G$ values were normal and the patient did not have any respiratory symptoms, we did not subject the patient to dialysis. In a patient of obstructive uropathy, timely decompression may result in complete recovery of renal function..$^{1}$ Decision to dialyse should not be undertaken on the basis of elevated serum creatinine alone; in this patient serum creatinine was $14.7 \mathrm{mg} \%$ at presentation and no dialysis was needed. Rather dialysis should be offered to patients presenting with refractory hyperkalaemia or hypervolaemia, ECG changes, uremic encephalopathy and respiratory decompensation.

In the past, large incisions were needed to extract urinary tract stones. With the advent of endourology, stones anywhere in the urinary tract may be managed in a minimally invasive fashion.

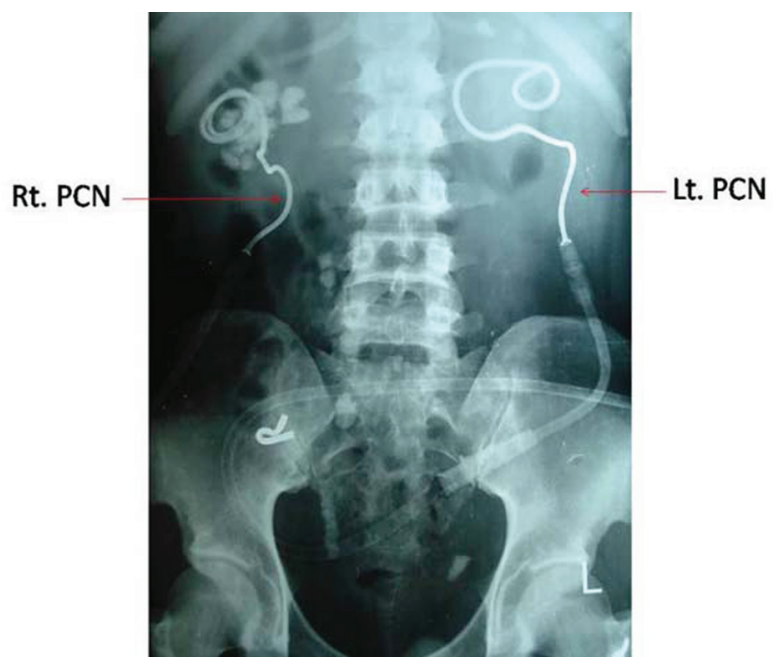

Figure 2 Plain skiagram KUB region after bilateral per cutaneous nephrostomies. 


\section{BMJ Case Reports}

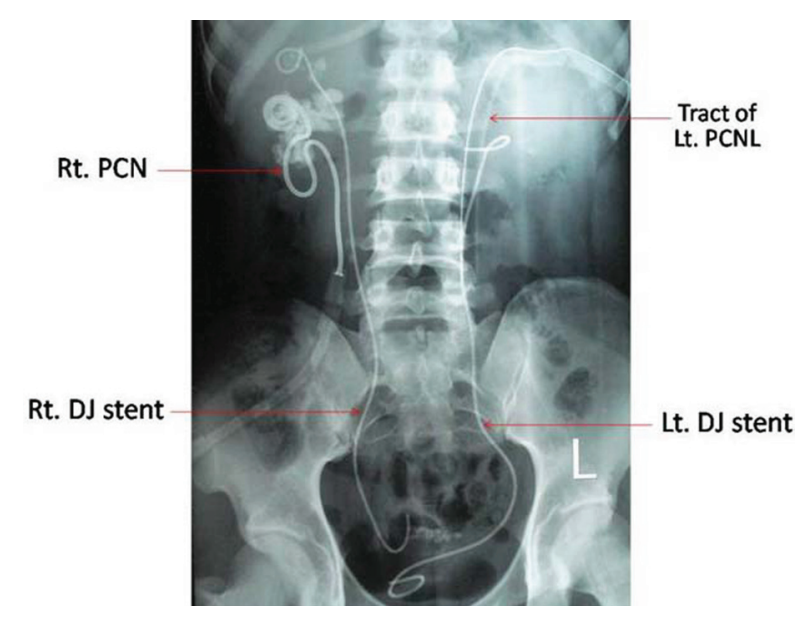

Figure 3 Plain skiagram KUB region after bilateral URS and left PCNL. Complete clearance of ureteric stones and left renal stone. Bilateral DJ stents seen.

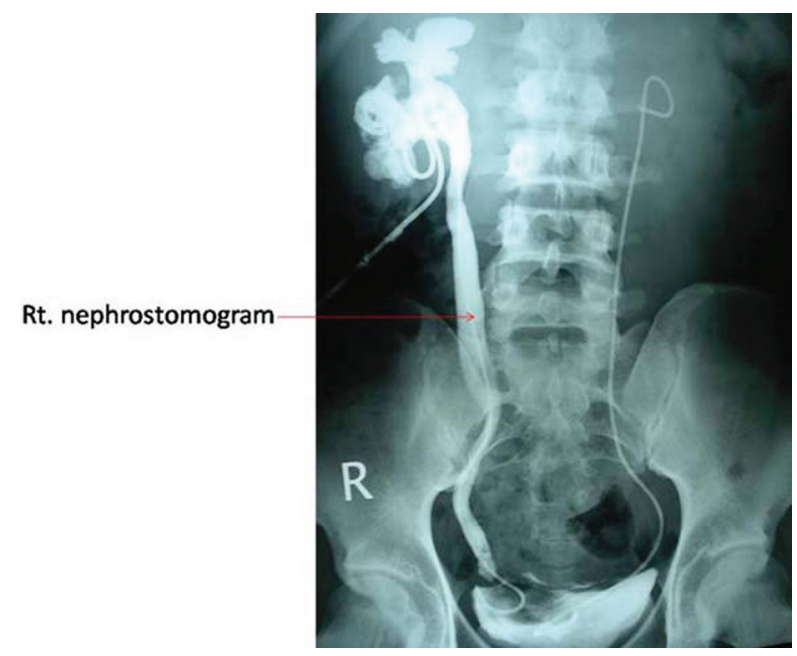

Figure 4 Right nephrostomogram delineating the pelvicalyceal anatomy and ureter.

The right kidney harboured multiple stones in all the calyces. Since we were using a rigid nephroscope, we had to make multiple punctures (upper, middle and lower calyces). Employing a flexible nephroscope could have decreased the number of renal punctures but would have increased the operative costs. ${ }^{2} \mathrm{PCNL}$, if correctly performed, results in minimal blood loss. In this patient, a total of four renal punctures were made (one on the left and three on the right) without the need for any blood transfusions.

Endourology is the gold standard for managing urolithiasis. ${ }^{3}$ No or very small incisions are made that reduces blood loss, avoids patient disfigurement and cuts down on the hospital stay and cost. As the procedures are carried under fluoroscopy, it ensures maximal stone clearance, which is so relevant in a patient like this.

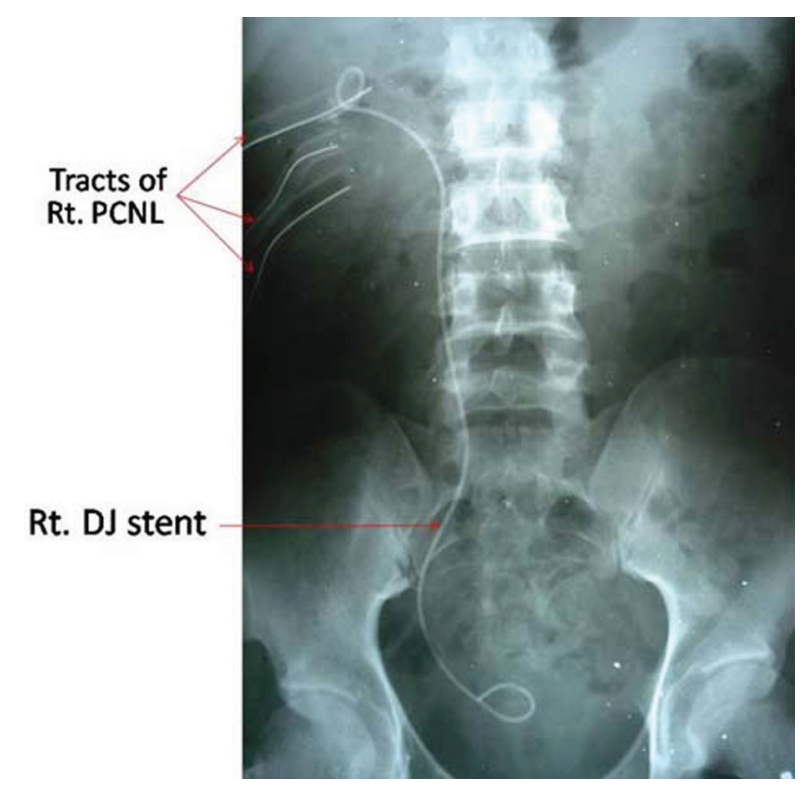

Figure 5 Plain skiagram KUB region after right PCNL. Complete clearance of right renal stones. Right DJ stent seen.

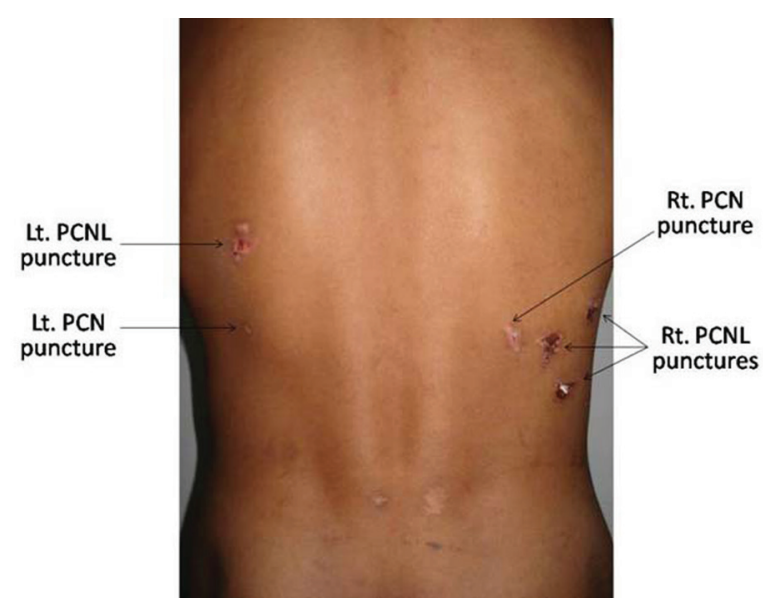

Figure 6 Various puncture sites completely healed.

Competing interests None.

Patient consent Obtained.

\section{REFERENCES}

1. Sood G, Sood A, Jindal A, et al. Ultrasound guided percutaneous nephrostomy for obstructive uropathy in benign and malignant diseases. Int Braz J Urol 2006;32:281-6.

2. Ganpule AP, Mishra S, Desai MR. Multiperc versus single perc with flexible instrumentation for staghorn calculi. J Endourol 2009;23:1675-8.

3. Lingeman JE, Matlaga BR, Evan AP. Surgical management of upper urinary tract calculi. In: Wein AJ, Kavoussi LR, Novick AC, Partin AW, Peters CA, eds. Campbell-Walsh Urology. 9th ed. Philadelphia, PA: Saunders-Elsevier 2007:1485-96. 


\section{BMJ Case Reports}

This pdf has been created automatically from the final edited text and images.

Copyright 2011 BMJ Publishing Group. All rights reserved. For permission to reuse any of this content visit http://group.bmj.com/group/rights-licensing/permissions.

BMJ Case Report Fellows may re-use this article for personal use and teaching without any further permission.

Please cite this article as follows (you will need to access the article online to obtain the date of publication).

Chaudhary R, Singh K, Biswas R, Chaudhary R, Jain N. A patient of severe acute renal failure secondary to obstructive uropathy with an optimal outcome. BMJ Case Reports 2011;10.1136/bcr.10.2010.3458, date of publication

Become a Fellow of BMJ Case Reports today and you can:

- Submit as many cases as you like

- Enjoy fast sympathetic peer review and rapid publication of accepted articles

- Access all the published articles

Re-use any of the published material for personal use and teaching without further permission

For information on Institutional Fellowships contact consortiasales@bmjgroup.com

Visit casereports.bmj.com for more articles like this and to become a Fellow 